\title{
Immunohistochemical and in situ Hybridization Studies on Endothelin in the Rat Eye
}

\author{
Tomoko Teramura ${ }^{1,2}$, Hisao Yamada ${ }^{1}$, Kazutaka Kani ${ }^{2}$ and Junzo Ochi ${ }^{1}$ \\ Departments of ${ }^{1}$ Anatomy and ${ }^{2}$ Ophthalmology, Shiga University of Medical Science, Otsu City, 520-21
}

Received for publication March 26, 1997 and in revised form May 20, 1997

\begin{abstract}
To demonstrate the distribution of endothelin (ET) in ocular tissues, we immunohistochemically elucidated the localization of ETs (ET-1, ET-2, ET-3) and their precursors (Big ETs) using specific antibodies that can distinguish precursor and mature types of each isopeptide. ET-A receptor and ET-1 and ET-3 mRNAs were also examined using immunohistochemical and in situ hybridization methods, respectively. Coincidentally, the positive reactivity for ET-1 and ET-3 mRNAs, Big ET-1, Big ET-2, Big ET3, mature ETs and ET-A receptor was found in almost the same element of the rat ocular
\end{abstract}

tissues, e.g., the retinal neural cells (ganglion, amacrine, bipolar and horizontal cells), the vessel walls in the retina and choroid, the non-pigment epithelium in the ciliary body and iris, the corneal epithelium (anterior surface) and the endothelium (posterior surface), and the epithelium of the lens. These observations indicated that the various ocular tissues biosynthesize and secrete all the isopeptides of ET which act in an autocrine/paracrine fashion, regulating the neural transmission, intraocular pressure, iris smooth muscle tone and ocular blood vessel tone.

Key words: Endothelin, Rat, Eye, Immunohistochemistry, In situ hybridization

\section{Introduction}

A powerful vasoactive peptide, endothelin (ET), which contains 21 amino-acids, was first purified from porcine aortic endothelial cells [25]. To date, it has been shown that ET consists of three isopeptides, ET-1, ET-2, and ET-3 [4]. Each mature peptide of ETs (mature ET-1, mature ET-2 and mature ET-3) is derived from the intermediate precursor, Big ET-1, Big ET-2 or Big ET-3, respectively. These mature ET-peptides combine with two distinct receptors, type A receptor (ET-AR) [19] and type B receptor (ET-BR) [1], both of them are G proteincoupled receptors with seven-transmembrane domains.

Besides the initial conception that ET is a vasoconstrictor peptide, ET is thought to have various physiological functions in the mammalian body [23]. We propose that ET belongs to the group of "brain vascular peptide hormones" because of its two major biological functions, i.e., regulation of neural transmission and vascular tonus [22,

Selected by "The 10th International Congress of Histochemistry and Cytochemistry" held in Kyoto, Japan on Aug. 18-23, 1996.

Correspondence to: Dr. Hisao Yamada, Department of Anatomy, Shiga University of Medical Science, Seta-Tsukinowacho, Otsu City, Shiga 520-21, Japan.
23]. Consecutive studies in our laboratory elucidated that ET exists in many organs, i.e., the brain $[6,7,21]$, the lacrimal gland [12], the submandibular gland and the lung [5], and the gastrointestinal tract [8], as well as the cardiovascular system [13].

In the ocular tissues, several reports have demonstrated the existence of ET-peptides [2, 10], their mRNAs [9] and their binding sites $[9,11,17]$. Moreover it is thought that the role of ETs in ocular tissues is to regulate micro-circulation in the retina, choroid, and optic nerve head, and to influence intraocular pressure $[3,10$, 14-18, 20]. However, the localization of ET-peptides, their mRNA and their receptors in all the tissues of the eye has not yet been precisely revealed.

In this study, we histochemically revealed the distribution of Big ET-1, Big ET-2, Big ET-3, mature ETs, ET-1 mRNA, ET-3 mRNA and ET-AR in the eye (retina, choroid, ciliary body, iris, cornea and lens) at the cellular level. Moreover, we discuss the roles of ETs in connection with their distributions. The preliminary results were presented at the 10th International Congress of Histochemistry and Cytochemistry [21]. 


\section{Materials and Methods}

\section{Experimental Animals and Tissue Preparation}

All experimental animals used in this study were male Wistar rats (Nippon Clea, Tokyo, Japan) weighing 200 to $300 \mathrm{~g}$. The rats were kept in the Experimental Animal Institute at the University, and treated in accordance with the Guideline for Animal Experimentation (Japanese Association for Laboratory Animal Science).

Under anesthesia by an intraperitoneal injection of 40 $\mathrm{mg} / \mathrm{kg}$ pentobarbital, the rats were perfused with an icecold fixative containing $4 \%$ formaldehyde and $0.2 \%$ picric acid buffered with $100 \mathrm{mM}$ sodium-phosphate (pH 7.2). After the eye balls were enucleated immediately, they were further fixed for $12 \mathrm{hr}$ at $4{ }^{\circ} \mathrm{C}$, rinsed in $10 \%$ sucrose in phosphate-buffered saline $(0.9 \% \mathrm{NaCl}$ in $100 \mathrm{mM}$ sodiumphosphate, $\mathrm{pH} 7.2$ : PBS) for $24 \mathrm{hr}$, followed by incubation in 20\% sucrose in PBS for more than 2 days. Sections (16 to $20 \mu \mathrm{m}$ in thick) were obtained using a cryostat and thaw-mounted on silane-coated glass slides. The histochemical procedure has been described in detail elsewhere $[5,6,13,24]$.

\section{Immunohistochemistry}

The sections were incubated in $0.3 \% \mathrm{H}_{2} \mathrm{O}_{2}$ in PBS at room temperature for $3 \mathrm{hr}$ to inactivate the endogenous peroxidase activity, followed by a $10 \mathrm{~min}$ rinse in PBS. Subsequently, sections were immunostained with the avidin-biotin-peroxidase complex method, using the five kinds of primary antibodies. The polyclonal anti-Big ET-1, anti-Big ET-2 and anti-Big ET-3 antibodies were purchased from Peptide Inst. Inc. (Osaka, Japan). Antimature ETs antibody (rabbit polyclonal) which was produced in our laboratory [5, 24], recognizes only the C-terminus of all mature ET-isopeptides, but not any precursor, Big ETs. The rabbit polyclonal antibody to ET-AR also prepared in our laboratory $[6,24]$ recognizes C-terminal 64 amino-acids residue (final intracellular domain) of this $\mathrm{G}$ protein-coupled receptor with seventransmembrane domain. We used these antibodies in concentrations ranging from $1: 2000$ to $1: 4000$. After 5 days' incubation with primary antibodies at $4^{\circ} \mathrm{C}$, the sections were washed in three changes of PBS for $30 \mathrm{~min}$ at room temperature. Then they were incubated in biotinylated anti-rabbit IgG goat serum (Vector Lab. Inc., Burlingame, CA, U.S.A.) for $3 \mathrm{hr}$, followed by rinse with PBS; and then incubated with the avidin-biotin-peroxidase complex solution (Vector Lab. Inc.) for $80 \mathrm{~min}$ at room temperature. After washing with PBS, they were reacted with 3,3'-diaminobenzidine solution $(20 \mathrm{mg}$ in $100 \mathrm{ml}$ of $50 \mathrm{mM}$ Tris- $\mathrm{HCl}$ buffer, $\mathrm{pH} 7.6)$ containing $20 \mu \mathrm{l}$ of $30 \%$ $\mathrm{H}_{2} \mathrm{O}_{2}$ for $15 \mathrm{~min}$ at room temperature. Finally, sections were rinsed with PBS, counterstained with hematoxylin, dehydrated in alcohol and mounted with Entellan (Merck Co., Darmstadt, Germany).

To determine the type of amacrine cells, ET-AR was immunostained with avidin-biotin-alkaline phosphatase complex method (Vector Lab. Inc.), after tyrosine hydroxylase was immunostained with the above mentioned immunohistochemical procedure using anti-tyrosine hydroxylase antibody (Eugene Tech Int. Inc., Ridgefield Park, NJ, U.S.A.).

\section{In Situ Hybridization}

The cDNAs corresponding to nucleotide position 50483 of rat ET-1 mRNA and position 917-1457 of human ET-3 mRNA were subcloned into the multiple cloning site of the plasmid pSPT18 (for ET-1) or pBluescript II (for ET-3) [13, 24]. After linealization, the cRNA probes were labeled with a digoxigenin labeling kit (DIG cRNA kit: Boehringer-Mannheim-Yamanouchi, Tokyo, Japan).

After prehybridization for $24 \mathrm{hr}$ at $50^{\circ} \mathrm{C}$ in a solution consisting of $4 \times$ salined-sodium citrate (SSC; $1 \times$ $\mathrm{SSC}=150 \mathrm{mM}$ sodium chloride, $15 \mathrm{mM}$ sodium citrate), $50 \%$ de-ionized formamide, $5 \times$ Denhardt's reagent $(1 \times$ Denhardt's reagent $=0.02 \% \quad$ Ficoll, $\quad 0.02 \%$ polyvinylpyrolidone, $0.02 \%$ RNase-free bovine serum albumin), hybridization was performed in $4 \times \mathrm{SSC}, 50 \%$ de-ionized formamide, $1 \times$ Denhardt's reagent, $0.2 \%$ Tween 20, $250 \mu \mathrm{g} / \mathrm{ml}$ tRNA, $500 \mu \mathrm{g} / \mathrm{ml}$ fragmented salmon sperm DNA and digoxigenin-labeled RNA probe, for $72 \mathrm{hr}$ at $50^{\circ} \mathrm{C}$. For the prehybridization and hybridization, $200 \mu \mathrm{l}$ and $100 \mu \mathrm{l}$ of solution, respectively, was applied to each section and covered by a parafilm slip. Then the sections were rinsed in three changes of $2 \times \mathrm{SSC}$ for $15 \mathrm{~min}$; two changes of $0.2 \times \mathrm{SSC}$ for $10 \mathrm{~min}$ at room temperature; $0.2 \times \mathrm{SSC}$ for $10 \mathrm{~min}$ at $50^{\circ} \mathrm{C}$; and $\mathrm{PBS}$ for $5 \mathrm{~min}$ at room temperature.

After hybridization steps, the sections were incubated in 5\% sheep serum in PBS containing 0.4\% Triton X-100 at room temperature for $2 \mathrm{hr}$ and then incubated with the alkaline phosphatase labeled anti-digoxigenin antibody (Boehringer-Mannheim-Yamanouchi, Tokyo, Japan: concentration $1: 1000$ ) in the same solution for $24 \mathrm{hr}$. After incubation, sections were washed in five changes of $100 \mathrm{mM}$ Tris-HC1 buffer (pH 7.6) containing $150 \mathrm{mM}$ $\mathrm{NaCl}$ and $0.2 \%$ Tween 20 for $20 \mathrm{~min}$ at room temperature, and then incubated in $100 \mathrm{mM}$ Tris-HC1 (pH 9.5) buffered solution containing $100 \mathrm{mM} \mathrm{NaCl}, 50 \mathrm{mM} \mathrm{MgCl}, 0.4 \%$ Triton X-100 and $1 \mathrm{mM}$ levamisol for $30 \mathrm{~min}$. Thereafter, sections were incubated in $45 \mu \mathrm{l}$ of nitro blue tetrazolium (75 mg/70\% N,N'-dimethylformamide) solution and $35 \mu \mathrm{l}$ of 5-bromo-4-chloro-3-indolylphosphate- $p$-toluidine salt (50 mg/100\% N,N'-dimethylformamide)/10 ml reaction buffer in the dark room for $0.5-24 \mathrm{hr}$. The reaction was stopped by immersion in $100 \mathrm{mM}$ EDTA (pH 8.0) for $1 \mathrm{~min}$, and the sections were mounted with Aquatex (Merck Co.).

\section{Results}

The reaction products of immunohistochemical staining (brown color) for Big ET-1, Big ET-2, Big ET-3, mature ETs and ET-AR, and in situ hybridization staining 
(blue color) for ET-1 mRNA and ET-3 mRNA were diffusely observed in the cytoplasm of the positive cells, e.g., the retinal neural cells, the vessel walls in retina and choroid, the non-pigment epithelium in the ciliary body and iris, the corneal epithelium and endothelium, and the epithelium of lens (Table 1). When the antibody preabsorbed by its epitope peptide $(10 \mu \mathrm{M})$ was used in the immunohistochemical procedure or a sense probe was used in the in situ hybridization histochemistry as negative control staining, no positive reactivity was found.

In the retina, the immunoreactivity for Big ET-1 was observed in almost all the ganglion cells, and in approximately $20 \%$ of the smaller cells (both the bipolar and horizontal cells) in the internal nuclear layer, and in the retinal pigment epithelial cells (Fig. 1A). Weak reactivity was also found in several amacrine cells, and the internal plexiform layer where the reactivity showed a diffuse and dot-like pattern (Fig. 1A). Along with these results, the endothelial cells of the blood vessels in the choroid also showed quite positive for Big ET-1 (Fig. 1A). The immunohistochemistry for Big ET-2 and Big ET-3 showed almost the same results as those of the Big ET-1. However, using anti-Big ET-2 or Big ET-3 antibodies, the positive reactions of the nerve fibers from the ganglion cells were significantly strong; and the diffuse and dot-like immunoreactivity in the internal plexiform layer was somewhat strong; while the reactivity in the vessel wall was not strong; the retinal pigment epithelium showed no significant reaction (Fig. 1B). In the case of immunohistochemistry for mature ETs, the positive reactivity in the ganglion cells was very strong, while that in the nerve fibers was very low (Fig. 1C). The strong immunopositive reaction of ET-AR appeared in the perikarya of the tyrosine hydroxylase-immunopositive amacrine cells. Medium to weak reactivity of ET-AR was found in the ganglion cells and their nerve fibers; and also in the internal plexiform layer showing a diffuse and dot-like pattern (Fig. 1D).

With in situ hybridization methods, positive stains for both ET-1 and ET-3 mRNAs were observed in the perikarya of the ganglion cells and smaller cells (both bipolar and horizontal cells) in the internal nuclear layer (Fig. 1-E, F). Their reactivities were also scattered in the external plexiform layer. In the choroid, quite positively stained cells were found using ET-1 mRNA in situ hybridization. The retinal pigment epithelial cells contained only ET-1 mRNA when examined using in situ hybridization methods.

In the ciliary body, all the non-pigment epithelial cells, which are cuboidal cells arranged in the superficial layer, showed positive immunoreactivity to all antibodies used in this study (Fig. 1G), as well as positive reaction to cRNA probes for both ET-1 and ET-3 mRNAs. In the iris, superficial epithelial cells, which correspond to the non-pigment epithelial cells in the ciliary body showed a positive reaction to all the histochemical procedures in this study (Fig. 1-H, I). The vascular endothelial cells in the ciliary body and iris were immunostained with anti-Big ET-1 antibody. Some stromal cells and some vascular smooth muscle cells in the iris had ET-AR-immunoreactivity.

The corneal epithelium, which covers the front of the cornea and is formed by five cell-layers had a positive reaction to Big ET-3, mature ETs, ET-AR and ET-3 mRNA, especially in its deep layers (Fig. 1J). All the corneal endothelium of the anterior chamber showed immuno-

Table 1. The distribution and staining intensity of ET-1 mRNA, Big ET-1, Big ET-2, ET-3 mRNA, Big ET-3, mature ETs and ET$A R$ in various cells and tissues of the rat eye.

\begin{tabular}{|c|c|c|c|c|c|c|c|}
\hline & ET-1 mRNA & Big ET-1 & Big ET-2 & ET-3 mRNA & Big ET-3 & mature ETs & ET-AR \\
\hline RETINA & & & & & & & \\
\hline nerve fibers & - & + & ++ & - & +++ & + & + \\
\hline ganglion cells & ++ & + & + & ++ & + & +++ & + \\
\hline internal plexiform layer & - & + & + & - & ++ & + & + \\
\hline $\begin{array}{c}\text { internal nuclear layer } \\
\text { amacrine cells }\end{array}$ & - & $-\sim+$ & - & - & - & $-\sim+$ & $+t$ \\
\hline bipolar cells & $-\sim+$ & $-\sim+$ & $-\sim+$ & $-\sim+$ & $-\sim+$ & $-\sim+$ & - \\
\hline horizontal cells & $-\sim+$ & $-\sim+$ & $-\sim+$ & $-\sim+$ & $-\sim+$ & $-\sim+$ & $-\sim+$ \\
\hline retinal pigment epitheliun & + & + & - & - & - & + & + \\
\hline CHROID & & & & & & & \\
\hline vascular walls & ++ & ++ & - & - & - & + & + \\
\hline CILIARY BODY & & & & & & & \\
\hline non pigment epithelium & ++ & ++ & ++ & ++ & ++ & ++ & ++ \\
\hline$\overline{\text { IRIS }}$ & & & & & & & \\
\hline non pigment epithelium & + & + & + & + & + & + & + \\
\hline CORNEA & & & & & & & \\
\hline $\begin{array}{l}\text { epithelium } \\
\text { endothelium }\end{array}$ & $\begin{array}{c}-\sim+ \\
++\end{array}$ & $\begin{array}{c}-\sim+ \\
++\end{array}$ & $\begin{array}{c}-\sim+ \\
++\end{array}$ & $\begin{array}{c}+ \\
++\end{array}$ & $\begin{array}{c}+ \\
++\end{array}$ & $\begin{array}{c}+ \\
++ \\
+\end{array}$ & $\begin{array}{l}+ \\
+ \\
\end{array}$ \\
\hline LENS & & & & & & & \\
\hline epithelium & - & - & + & + & + & + & $-\sim+$ \\
\hline
\end{tabular}

$(+++)$ : very high intensity; $(++)$ : medium intensity; $(+)$ : low intensity; $(-)$ : negative. $(-\sim+)$ means some of them are positive. 



Fig. 1. Microphotographs show the sections of the rat retina $(\mathbf{A}-\mathbf{F})$, ciliary body $(\mathbf{G})$, iris $(\mathbf{H}$, $\mathbf{I})$, cornea (J) and lens (K) stained with immunohistochemistry for Big ET-1 (A), Big ET-2 (B), Big ET-3 (K), mature ETs (C, G, I, J) and ET-AR (D); and using in situ hybridization methods for ET-1 mRNA (E) and ET-3 mRNA (F, H). The double-immunohistochemical staining (L) shows co-existence of tyrosine hydroxylase (brown) and ET-AR (blue) in the amacrine cell of the rat retina. A-K: $\times 350, \quad \mathbf{L}: \times 650$. 
positive reaction to all isopeptides of both Big and mature forms (Fig. 1J), and positive reaction to ET-1 and ET-3 mRNAs. A positive reaction to ET-AR in the endothelium was also found. In the other layers of cornea and in the sclera, there was no positive histochemical reaction.

In the lens, the immunoreactivities for mature ETs, Big ET-2, Big ET-3 and ET-AR (but not Big ET-1) were diffusely found in the simple cuboidal epithelial cells (Fig. 1K). ET-3 mRNA was also seen in their perinuclear region. In other regions of the lens, i.e., the capsule and lental fibers, no positive reaction was detected.

\section{Discussion}

Our results indicate that ET peptides are present in various tissues in the eye, including not only vessel walls, but also neural tissues and the epithelia. The present immunohistochemical and in situ hybridization findings are summarized in Table 1. Each of our histochemical results ascertained by control staining, is consistent in the results obtained in the histochemical procedures in the present studies. As we describe below, they are also fundamentally in agreement with the previous biochemical and pharmacological studies.

Recently, some researchers reported the presence of ETs in ocular tissues. Using Northern blot and in situ hybridization analysis, ET (probable ET-1) mRNA is observed in the ciliary body, iris and choroid in the rat at a low resolution level [9]. The distribution of ET-peptides in various mammals was more precisely analyzed using radio-immuno-assay $[2,10]$. These reports described that ET-1 and ET-3 were present in high concentrations in the ciliary body and iris, in lower concentrations in the retina and choroid, and in very low concentration in the cornea; and that the immunoreactivity of ET-3 was generally twoto three-fold higher than those of ET-1. This ETimmunoreactivity in the retina is thought to be associated with the blood vessels [2]. Thus the histological distribution of every ET-peptide has not been convincingly demonstrated, however, our results were fundamentally not contradictory to the previous biochemical and pharmacological studies $[2,9,10]$. The present report provides the precise histological distribution of not only ET-1 and ET-3, but also ET-2 at a high resolving level. In addition, their precursor and mature forms were able to be distinguished with our multi-histochemical procedure. Moreover, these findings were confirmed by the mRNA level using in situ hybridization methods. In the present study, mRNA of ETs, its precursor peptide and mature type (secretion type) were coincidentally present in the same region, suggesting their co-existence in identical cells. This indicates "biosynthesis and secretion" of ET in those ocular cells $[23,24]$. A new discovery in our study showed that ET-peptides are also present in nonvascular tissues in the eye. In particular, it clarified that neural elements in the retina contain the peptides and mRNAs of
ETs and their receptor. The ET mRNAs were localized in the perikarya and proximal part of their nerve fibers, while these peptides were found in not only the perikarya in the internal nuclear and ganglion cell layers, but also in their nerve fibers and terminals in the internal plexiform and nerve fiber layers. The amacrine cells with positive immunoreaction for ETs and ET-AR in this study were determined to be dopaminergic type using the doubleimmunohistochemical procedure with anti-tyrosine hydroxylase-antibody (Fig. 1L).

The binding site of radio-labeled ETs was demonstrated using autoradiographic histochemistry [9, $11,17]$. In their reports, ET-1 binding sites were localized in some retinal neural cells, retinal and choroidal blood vessels, the epithelium of ciliary body and iris, and the corneal endothelium or epithelium. However, analysis of antagonistic effects of ET-3 revealed that probable ET-AR existed only in the blood vessel walls, whereas probable ET-BR was present in the retinal neural cells [11]. Moreover, it demonstrated that only the ET-BR mRNA was found in the ciliary body and iris of the rabbit and rat using reverse transcription-polymerase chain reaction method [17]. Since we were not able to obtain adequate antibody to ETBR, no information on the distribution of ET-BR could be obtained. It seems that our histochemical findings on ETAR contradict the previous reports $[11,17]$ on the distribution of ET-BR in the eye. However, as Osborne et al. mentioned in their pharmacological study [17], it is thought that more than one type of ET receptors are present in these tissues. Sugiyama et al. [20] also demonstrated that intravitreal administration of ET-AR antagonist blocked ET-induced reduction of intraocular pressure. These findings indicate the possible distribution of ET-AR in non-vascular ocular tissues. Therefore, our findings on the cellular distribution of ET-AR at the peptide level, may give additional information.

In the present study, we did not immunostain ETs and their receptors simultaneously. However, the present findings indicate that at least some of them are co-localized in the identical cells, and others are present in close proximity to each other. This suggests local action of this peptide as an autocrine/paracrine humoral agent.

As the physiological and pharmacological actions of ETs, it is largely believed that ETs have various effects on the tonus of iris sphincter muscle [17], and the regulation of micro-circulation in the retina [18], choroid [14], and the optic nerve head [16], and intraocular pressure [3, 15, 20]. These studies presumed that neuro-electrophysiological changes and reduction of intraocular pressure after administration of ETs, were associated with the regulation of blood flow by ETs, but not with the regulation of neural transmission. The present results provide new evidence that ET is also involved in regulating neural transmission in the retina. In conclusion, the various ocular tissues biosynthesized and secrete all the isopeptides of ET which act in an autocrine/paracrine fashion, regulating neural transmission, intraocular 
pressure, iris smooth muscle tone and ocular blood vessel tone.

\section{Acknowledgment}

This work was supported by Grant-in-Aid for Scientific Research (No. 06808079) from the Ministry of Education, Science, Sports and Culture, Japan.

\section{References}

1. Arai, H., Hori, S., Aramori, I., Okubo, H. and Nakanishi, S.: Cloning and expression of a cDNA encoding an endothelin receptor. Nature 348; 730-732, 1990.

2. Chakravarthy, U., Douglas, A. J., Bailie, J. R., McKibben, B. and Archer, D. B.: Immunoreactive endothelin distribution in ocular tissues. Invest. Ophthalmol. Vis. Sci. 35; 2448-2454, 1994.

3. Grandstam, E., Wang, L. and Bill, A.: Effects of endothelins (ET-1, ET-2 and ET-3) in the rabbit eye; role of prostaglandins. Eur. J. Pharmacol. 194; 217-223,1991.

4. Inoue, A., Yanagisawa, M., Kimura, S., Kasuya, Y., Miyauchi, T., Goto, K. and Masaki, T.: The human endothelin family: Three structurally and pharmacologically distinct isopeptides predicted by three separate genes. Proc. Natl. Acad. Sci. U.S.A. 86; 2863-2867, 1989.

5. Katsura, A., Yamada, H. and Ochi, J.: An ontogenetic study on endothelin-producing cells in the rat lung and submandibular gland. Acta Histochem. Cytochem. 26; 373-379, 1993.

6. Kurokawa, K., Yamada, H. and Ochi, J.: Histochemical studies on endothelin, a brain-vascular peptide. II. Distribution in hypothalamus. Acta Histochem. Cytochem. 29 (Suppl.); 431-432, 1996.

7. Kurokawa, K., Yamada, H. and Ochi, J.: Endothelin-induced c-fos expression in the rat forebrain. Acta Histochem. Cytochem. 30; 17-22, 1997.

8. Liu, Y., Yamada, H. and Ochi, J.: Histochemical studies on endothelin, a brain-vascular peptide. V. Distribution in gastrointestinal tract. Acta Histochem. Cytochem. 29 (Suppl.); 437-438, 1996.

9. MacCumber, M. W., Ross, C. A., Glaser, B. M. and Snyder, S. H.: Endothelin: Visualization of mRNA by in situ hybridization provides evidence for local action. Proc. Natl. Acad. Sci. U.S.A. 86; 7285-7289, 1989.

10. MacCumber, M. W., Jampel, H. D. and Snyder, S. H.: Ocular effects of the endothelins: Abundant peptides in the eye. Arch. Ophthalmol. 109; 705-709, 1991.

11. MacCumber, M. W. and D'Anna, S. A.: Endothelin receptorbinding subtypes in the human retina and choroid. Arch. Ophthalmol. 112; 1231-1235, 1994.

12. Matsumoto, Y., Ishibashi, Y., Niiya, A., Yamada, H., Kurokawa, K. and Kinoshita, S.: Distribution of endothelin and endothelin-A receptor in the lacrimal glands of the monkey (Macaca fuscata). Exp. Eye Res. 64; 127-132, 1997.

13. Nishimura, T., Yamada, H., Kinoshita, M. and Ochi, J.: Endothelin expression during rat heart development: An immunohistochemical and in situ hybridization study. Biomed. Res. 15; 291-298, 1994.

14. Okada, D.: Effects of endothelin on choroidal circulation. II. Local circulation. Folia Ophthalmol. Jpn. 45; 393-397, 1994.

15. Okada, K., Sugiyama, K., Haque, S. R., Taniguchi, T. and Kitazawa, Y.: Biphasic intraocular pressure response to intravitreal injection of endothelin-1. J. Jpn. Ophthalmol. Soc. (Nippon Ganka Gakkai Zasshi) 98; 935-941, 1994.

16. Oku, H., Sugiyama, T., Moriya, S., Hamada, J. and Azuma, I.: Effects of intravitreal injection of endothelin on the visual system. J. Jpn. Ophthalmol. Soc. (Nippon Ganka Gakkai Zasshi) 97; 467-473, 1993.

17. Osborne, N. N., Barnett, N. L. and Luttmann, W.: Endothelin receptors in the cornea, iris and ciliary processes. Evidence from binding, secondary messenger and PCR studies. Exp. Eye Res. 56; 721-728, 1993.

18. Sakaue, H., Kiryu, J., Takeuchi, A., Yamamoto, F. and Honda, Y.: Effect of endothelin on retinal blood vessels. J. Jpn. Ophthalmol. Soc. (Nippon Ganka Gakkai Zasshi) 96; 469-472, 1992.

19. Sakurai, T., Yanagisawa, M., Takuwa, Y., Miyazaki, H., Kimura, S., Goto, K. and Masaki, T.: Cloning of a cDNA encoding a non-isopeptide-selective subtype of the endothelin receptor. Nature 348; 732-735, 1990.

20. Sugiyama, K., Haque, S. R., Okada, K., Taniguchi, T., Hayakawa, T. and Kitazawa, Y.: The effect of an endothelin receptor antagonist, $97-139$, on intraocular pressure in rabbits. J. Jpn. Ophthalmol. Soc. (Nippon Ganka Gakkai Zasshi) 99; 271-276, 1995.

21. Teramura, T., Yamada, H., Kurokawa, K., Kani, K. and Ochi, J.: Histochemical studies on endothelin, a brain-vascular peptide. IV. Distribution in ocular tissues. Acta Histochem. Cytochem. 29 (Suppl.); 435-436, 1996.

22. Yamada, H. and Kurokawa, K.: Histocytochemical analysis of endothelin and its role in the central nervous system. In "Central Nervous System and Blood Pressure Control 1993", ed. by A. Goto, H. Kawamura and K. Kishi, Yubunsha Publishing, Tokyo, 1993, pp. 105-114.

23. Yamada, H. and Ochi, J.: Histochemical and functional aspects on the "brain-vascular peptides". Acta Anat. Nipn. (Kaibogaku Zasshi) 70; 422-435, 1995.

24. Yamada, H., Kurokawa, K., Nishimura, T. and Ochi, J.: Histochemical studies on endothelin, a brain-vascular peptide. I. Strategy to analyze its distribution and function. Acta Histochem. Cytochem. 29 (Suppl.); 429-430, 1996.

25. Yanagisawa, M., Kurihara, H., Kimura, S., Tomobe, Y., Kobayashi, M., Mitsui, Y., Yazaki, Y., Goto, K. and Masaki, T.: A novel potent vasoconstrictor peptide produced by vascular endothelial cells. Nature 332; 411-415, 1988. 